\title{
Thermal limits of krill species from the high-Arctic Kongsfjord (Spitsbergen)
}

\author{
Kim Huenerlage ${ }^{*}$, Friedrich Buchholz
}

\author{
Alfred Wegener Institute Helmholtz Centre for Polar and Marine Research, Am Handelshafen 12, 27570 Bremerhaven, \\ Germany
}

\begin{abstract}
The high-Arctic Kongsfjord is mainly influenced by cold Arctic water, but also receives input of warmer water from the Atlantic. In recent years, the proportion of Atlantic inflow from the south has increased. Concurrently, one temperate-boreal (Meganyctiphanes norvegica) and one subtropical-temperate (Nematoscelis megalops) krill species are now regularly found in the Kongsfjord, in addition to the previously prevailing arcto-boreal species Thysanoessa inermis and T. raschii. In light of the recent changes in these species' biogeographic distributions, we compared their physiological tolerances. Using non-invasive optical oxygen sensors, respiration measurements served to characterize metabolic responses to temperature variations. The 2 Thysanoessa spp. appeared more cold-stenotherm than the other 2 krill species: the upper level of their respiratory capacity was reached at $12^{\circ} \mathrm{C}$ and they were less tolerant of decreasing oxygen concentrations. This finding is consistent with their arcto-boreal distribution. In contrast, M. norvegica and $N$. megalops exhibited higher tolerance to temperature changes, robust nutritional condition and sexual maturity. Such physiological plasticity may explain the recent northward expansion of these species' geographic range.
\end{abstract}

KEY WORDS: Metabolic rates · Respiration - Thysanoessa inermis - Thysanoessa raschii . Meganyctiphanes norvegica $\cdot$ Nematoscelis megalops

Resale or republication not permitted without written consent of the publisher

\section{INTRODUCTION}

Ambient temperature is a major factor influencing a species' metabolic performance, and accordingly, its survival and distribution (Pörtner 2001, 2002). Quantification of species-specific metabolic thermal limits is therefore helpful to predict acclimatization of species impacted by global warming (Somero 2005). During the last decade, hydrographic studies have indicated a climatic shift within the Arctic, i.e. a transition to a warmer state. This change has been attributed to an increase in the strength of the West Spitsbergen Current conveying warm Atlantic waters to the system (e.g. Polyakov et al. 2007, Spielhagen et al. 2011). Concomitantly, boreal fauna have spread to higher latitudes (Hop et al. 2002, 2006, Zhukova et al. 2009, Buchholz et al. 2010, Kwasniewski et al. 2012). The hydrography of the high-Arctic Kongsfjord, located on the west coast of Spitsbergen $\left(79^{\circ} \mathrm{N}\right)$, alternates seasonally between dominance of cold Arctic coastal waters $\left(<0^{\circ} \mathrm{C}\right)$ and warm $\left(\geq 4^{\circ} \mathrm{C}\right)$ Atlantic waters (e.g. Hop et al. 2002, 2006, Svendsen et al. 2002). Within this coastal regime, the krill community consists of Thysanoessa inermis and its congener T. raschii (Timofeyev 1993, Weslawski et al. 2000). Both species have an arcto-boreal distribution and are common in the Barents Sea, Norwegian Fjords as well as at lower latitudes such as the Newfoundland and Labrador shelf $\left(45\right.$ to $50^{\circ} \mathrm{N}, 47$ to $55^{\circ} \mathrm{W}$; e.g. Einarsson 1945, Mauchline \& Fisher 1969, Timofeyev 1993, Buchholz et al. 2012). Recently, however, the increase in intrusion of warm Atlantic waters into the Kongsfjord has increased krill diversity. One species of temperate-boreal origin, Meganyctiphanes norvegica, and one species of subtropical-temperate origin, Nematoscelis megalops, are now found regularly 
in the Kongsfjord and adjacent waters (e.g. Buchholz et al. 2010, Huenerlage et al. 2014), providing an opportunity to address an important question: Will the phenotypic plasticity of these species allow all of them to persist at high latitudes?

Oxygen consumption is a useful indicator of species-specific metabolism as it serves as a proxy for the sum of physiological processes (e.g. Williams \& del Giorgio 2005). Accordingly, to investigate metabolic responses to changing temperatures, temperature-controlled experiments were conducted to assess the respiration rates of each krill species. Further, fresh weight, stomach content, hepatopancreas colour, sexual development stage and excretion rates of each species were determined to assay overall health.

\section{MATERIALS AND METHODS}

\section{Sample collection}

Adult krill were caught on-board the Kings Bay AS workboat 'MS Teisten' (Kongsfjord at $79^{\circ} \mathrm{N}$ ) using a $1 \mathrm{~m}^{2}$ Tucker trawl (1000 $\mu \mathrm{m}$ mesh with soft cod-end bucket). The trawls were towed at a speed of 2 knots. Additionally, adult Thysanoessa inermis were collected in a similar manner from the Polish RV 'Oceania' (Hornsund fjord at $77^{\circ} \mathrm{N}$ ). Detailed information on sampling locations is provided in Fig. 1 (see also Table 1). The hauls were taken from between 90 and $300 \mathrm{~m}$ depth, depending on the station and maxi-

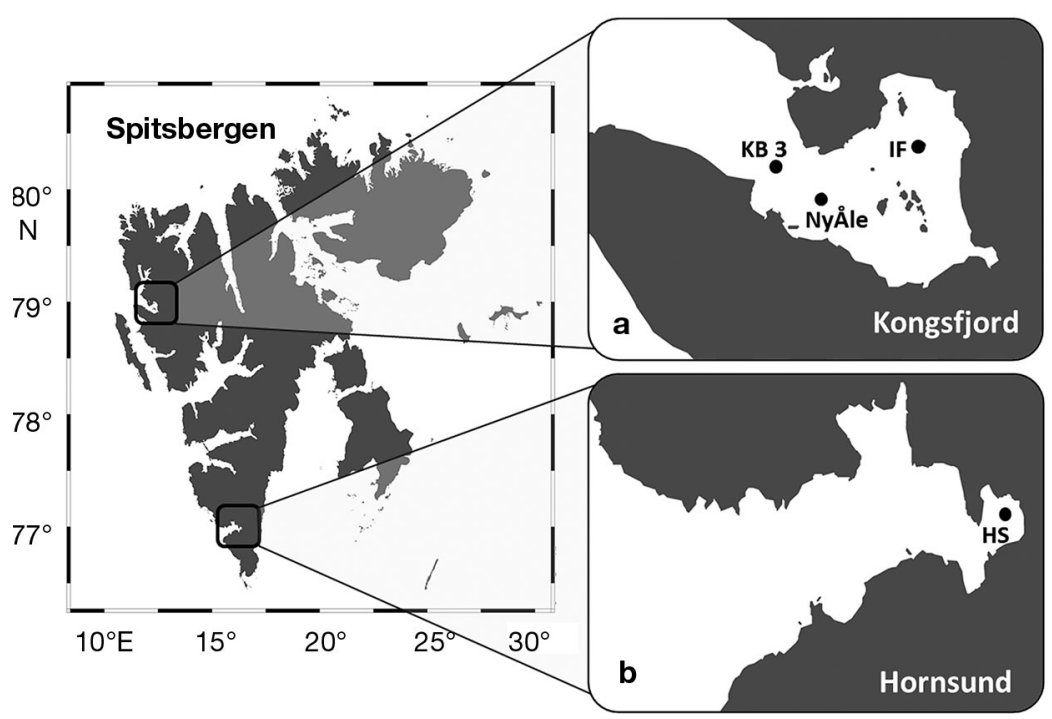

Fig. 1. Map of Spitsbergen; squares highlight the position of (a) the Kongsfjord and (b) the Hornsund fjord. See Table 1 for detailed station locations mum abundance at the stations sampled (F. Buchholz pers. obs.)

Immediately after collection, specimens were sorted by species and transferred to aerated aquaria filled with filtered seawater $(0.2 \mu \mathrm{m})$ at in situ temperature $\left(4^{\circ} \mathrm{C}\right)$ in dim light. After $12 \mathrm{~h}$, the specimens were brought to experimental temperatures (i.e. 0, 2, 6, 8, $10,12,14$ or $16^{\circ} \mathrm{C}$ ) at a rate of $1^{\circ} \mathrm{C} \mathrm{h}^{-1}$, followed by $12 \mathrm{~h}$ acclimation at constant specific experimental temperature before use in the respiration experiments. Hence, the total maintenance before measurement was not longer than $36 \mathrm{~h}$.

\section{Metabolic rate measurements}

Acclimated specimens were individually incubated in closed tubular chambers ( $\mathrm{n}=1$, Perspex; $20 \mathrm{ml}$ ) specially designed for measuring routine metabolic rates in krill (Werner et al. 2012). The chambers were filled with $0.2 \mu \mathrm{m}$ filtered seawater at each experimental temperature $\left(0,2,6,8,10,12,14\right.$ or $\left.16^{\circ} \mathrm{C}\right)$ and stored in a water bath in the dark in a temperaturecontrolled refrigerator. Two chambers were prepared without specimens and served as controls. Oxygen consumption (mg $\mathrm{O}_{2} \mathrm{l}^{-1}$ ) was monitored every $30 \mathrm{~s}$ by optode respirometry with a 10-channel optode respirometer (PreSens Precision Sensing Oxy-10 Mini). The measurements lasted 1.5 to $6 \mathrm{~h}$, depending on the individuals' metabolic rates, and were stopped at the latest when the oxygen concentration inside the test chambers reached $60 \%$ of the initial concentration.

After the experiments, individual specimens were scored under a stereomicroscope for sex, size (front of the eyes to tip of the telson, to the nearest $\mathrm{mm}$ ), fresh weight (FW, $\mathrm{mg})$, stomach fullness (STO), hepatopancreas colour (HPP) (Morris et al. 1983) and sexual development stage (SDS) (Cuzin-Roudy 1993). These parameters served as proxies for the species' overall health.

For the determination of ammonium $\left(\mathrm{NH}_{4}-\mathrm{N}\right)$ excretion, water samples $(500 \mu \mathrm{l})$ from each respiration chamber were frozen and stored at $-80^{\circ} \mathrm{C}$ until measurement. The analysis was done in triplicate and conducted photometrically following the phenol-hypochlorite method according to Solorzano (1969) using a 
microplate reader $\left(630 \mathrm{~nm}^{\text {; }}\right.$ Multiskan ${ }^{\mathrm{TM}}$ FC Microplate Photometer, Thermo Scientific).

The atomic oxygen to nitrogen ratio $(\mathrm{O}: \mathrm{N})$ was used as an indication of the substrate catabolized for energy provision: O:N $<24$ for protein and O:N > 24 for a lipid-dominated metabolism (Mayzaud \& Conover 1988).

\section{Minimum tolerable ambient oxygen concentration in $T$. inermis}

In another experiment, we investigated the minimum tolerable oxygen (MTO) concentration with increasing experimental temperature. Due to time limitations, the experiment was only conducted on $T$. inermis. The experimental setup was the same as for the metabolic rate measurements; however, the experiments were only conducted at 6 different temperatures $\left(2,4,6,8,10\right.$ and $16^{\circ} \mathrm{C} ; \mathrm{n}=8$ for each). Furthermore, this experiment used the optode respirometer to monitor the oxygen concentration $\left(\mathrm{mg} \mathrm{l}^{-1}\right)$ inside the chamber while the specimens' overall condition was monitored by eye. Measurements stopped as soon as a specimen became immobile but the heart was still beating.

\section{Data analyses}

Metabolic rates were normalized to $1 \mathrm{mg} F W$ and expressed in $\mu \mathrm{mol} \mathrm{h} \mathrm{h}^{-1}$. $Q_{10}$ values were calculated from respiration measurements according to van't Hoff (1884). The Arrhenius breakpoint temperatures (ABT) of the temperature-dependent oxygen consumption of $T$. inermis and $T$. raschii were estimated through 2-phase regression conducted on the Arrhenius plots of the corresponding respiration rates (Dahlhoff et al. 1991; see Fig. S1 in the Supplement at www.int-res.com/articles/suppl/m535p089_supp.pdf).

A 1-way ANOVA with post hoc Tukey's test was used for general species comparisons. A 1-way ANOVA with post-hoc Dunnett's test was performed to test for temperature influence on the specimens' respiration rates compared to the $4^{\circ} \mathrm{C}$ control temperature. The same test was used to compare the temperature effect on the MTO concentrations of T. inermis. Species-specific seasonal differences (autumn vs. spring) were analysed with an unpaired $t$-test. Species-specific differences between genders were either analysed with an unpaired $t$-test (male vs. female) or 1-way ANOVA (male vs. female vs. neuter).
All analyses were conducted using GraphPad Prism 5 (GraphPad Software). Results were considered significant at $\mathrm{p}<0.05$. All data are presented as means \pm standard error of the mean (SE).

\section{RESULTS}

In total, 437 euphausiids were sampled. Adult Thysanoessa inermis $(\mathrm{n}=282)$, Meganyctiphanes norvegica $(\mathrm{n}=85)$ and Nematoscelis megalops $(\mathrm{n}=$ 10) were sampled both in early spring (first week of April 2013) and early autumn (August 2012 and 2013). T. raschii was only sampled in early autumn $(\mathrm{n}=60$; Tables $1 \& 2)$. In all parameters investigated, no intraspecific differences were found based on gender; therefore, the data were pooled for interspecies and seasonal comparisons, respectively (e.g. Table 2, see Figs. 2 \& 4).

\section{Biometry and individual life parameters}

During early autumn, the species differed significantly in mean total body length and mean total FW ( $\mathrm{p}$ $<0.0001, F=53.4 ; \mathrm{p}<0.0001, F=47.3)$. With a mean total length of $27.9 \mathrm{~mm}$ and a mean FW of $166.2 \mathrm{mg}$, $M$. norvegica were the largest and heaviest individuals of the 4 krill species sampled, followed by $T$. inermis $(24.8 \mathrm{~mm}, 110.3 \mathrm{mg})$, T. raschii $(23.5 \mathrm{~mm}, 79.2 \mathrm{mg})$ and $N$. megalops (21.3 mm, $64.0 \mathrm{mg}$; Table 2). The difference was not significant between the species sampled in spring 2013. T. inermis, $M$. norvegica and $N$. megalops had the same body length (21.2 to $21.4 \mathrm{~mm}$ ) and the same FW (61.8 to $63.6 \mathrm{mg}$; Table 2).

The nutritional condition by measure of STO and HPP differed between species in both seasons $(\mathrm{p}<$ $0.0001, F=12.7$ in autumn; $\mathrm{p}<0.0001, F=16.6$ in spring). In both autumn and in spring, lowest stomach fullness was observed in $T$. inermis (STO 0.4; see Table 2); concomitantly, the hepatopancreas was colourless. The same was found in $T$. raschii in autumn (STO 0.7, colourless HPP) and in N. megalops in spring (STO 0.4, colourless HPP). In autumn, highest stomach fullness was observed in $M$. norvegica and $N$. megalops (STO $\sim 0.8$, orange/white HPP and STO 1.2, yellow HPP; Table 2). This difference was not significant. However, conspicuously, oil droplets were visible in some of the stomachs of the M. norvegica specimens. In spring 2013, M. norvegica had the highest stomach fullness (STO 1.2) and was the only species showing a coloured HPP (yellow/green; Table 2). 
Table 1. Krill species investigated with information on sampling period, station names and station positions (see also Fig. 1)

\begin{tabular}{|lcccccc|}
\hline Stn & \multicolumn{2}{c}{ Position } & Thysanoessa & $\begin{array}{c}\text { Thysanoessa } \\
\text { raschii }\end{array}$ & $\begin{array}{c}\text { Meganyctiphanes } \\
\text { norvegica }\end{array}$ & $\begin{array}{c}\text { Nematoscelis } \\
\text { megalops }\end{array}$ \\
\hline HS & 76.99 & 6.33 & End of Jul 2012 & - & - & - \\
KB3 & 78.96 & 1.97 & Apr 2013 & - & Apr 2013 & Apr 2013 \\
NyÅle & 78.94 & 2.08 & Aug 2013 & Aug 2013 & Aug 2012 & Aug 2012 \\
IF & 78.97 & 2.36 & Aug 2012 & Aug 2012 & - & - \\
& & & Aug 2013 & Aug 2013 & - \\
\hline
\end{tabular}

Table 2. Sex (percentage composition; $\mathrm{f}=$ female, $\mathrm{m}=$ male, $\mathrm{n}=$ neuter); (mean $\pm \mathrm{SE}$ ) total length (L), fresh weight $(\mathrm{FW})$, stomach fullness (STO; 0 to $2=$ empty to full); hepatopancreas colour $(\mathrm{HPP} ; \mathrm{C}=$ colourless, $\mathrm{O}=$ orange, $\mathrm{W}=\mathrm{white}, \mathrm{G}=\mathrm{green}, \mathrm{Y}=$ yellow) and sexual developmental stage (SDS) of adult krill species (Thysanoessa inermis, T. raschii, Meganyctiphanes norvegica and Nematoscelis megalops) sampled for respiration measurements. See Table 1 for details of the sampling periods

\begin{tabular}{|c|c|c|c|c|c|c|c|c|}
\hline Species & Season & $\mathrm{n}$ & $\begin{array}{l}\text { Sex (\%) } \\
\text { (f:m:n) }\end{array}$ & $\begin{array}{c}\mathrm{L} \\
(\mathrm{mm})\end{array}$ & $\begin{array}{l}\text { FW } \\
(\mathrm{mg})\end{array}$ & STO & HPP & SDS \\
\hline T. inermis & $\begin{array}{c}\text { Autumn } \\
\text { Spring }\end{array}$ & $\begin{array}{c}201 \\
81\end{array}$ & $\begin{array}{c}46: 34: 20 \\
23: 70: 7\end{array}$ & $\begin{array}{l}24.8 \pm 0.1 \\
21.2 \pm 0.2\end{array}$ & $\begin{array}{c}110.3 \pm 1.9 \\
61.8 \pm 2.3\end{array}$ & $\begin{array}{l}0.4 \pm 0.1 \\
0.4 \pm 0.1\end{array}$ & $\begin{array}{l}\mathrm{C} \\
\mathrm{C}\end{array}$ & $\begin{array}{l}\text { Inactive } \\
\text { Active }\end{array}$ \\
\hline T. raschii & $\begin{array}{c}\text { Autumn } \\
\text { Spring }\end{array}$ & $\begin{array}{l}60 \\
-\end{array}$ & $\begin{array}{c}67: 33: 0 \\
-\end{array}$ & $\begin{array}{c}23.5 \pm 0.2 \\
-\end{array}$ & $\begin{array}{c}79.2 \pm 2.4 \\
-\end{array}$ & $\begin{array}{c}0.7 \pm 0.1 \\
-\end{array}$ & $\begin{array}{l}\mathrm{C} \\
-\end{array}$ & $\begin{array}{c}\text { Males active } \\
-\end{array}$ \\
\hline M. norvegica & $\begin{array}{c}\text { Autumn } \\
\text { Spring }\end{array}$ & $\begin{array}{l}54 \\
31\end{array}$ & $\begin{array}{c}39: 44: 17 \\
43: 50: 7\end{array}$ & $\begin{array}{l}27.9 \pm 0.5 \\
21.3 \pm 0.8\end{array}$ & $\begin{aligned} 166.2 & \pm 10.6 \\
61.8 & \pm 5.9\end{aligned}$ & $\begin{array}{l}0.8 \pm 0.1 \\
1.2 \pm 0.1\end{array}$ & $\begin{array}{l}\mathrm{O} / \mathrm{W} \\
\mathrm{Y} / \mathrm{G}\end{array}$ & $\begin{array}{c}\text { Males active } \\
\text { Active }\end{array}$ \\
\hline N. megalops & $\begin{array}{c}\text { Autumn } \\
\text { Spring }\end{array}$ & $\begin{array}{l}7 \\
3\end{array}$ & $\begin{array}{l}29: 71: 0 \\
67: 33: 0\end{array}$ & $\begin{array}{l}21.3 \pm 0.5 \\
21.4 \pm 0.4\end{array}$ & $\begin{array}{l}64.0 \pm 4.6 \\
63.6 \pm 2.6\end{array}$ & $\begin{array}{l}1.2 \pm 0.2 \\
0.4 \pm 0.1\end{array}$ & $\begin{array}{l}\mathrm{Y} \\
\mathrm{C}\end{array}$ & $\begin{array}{l}\text { Active } \\
\text { Active }\end{array}$ \\
\hline
\end{tabular}

Maturity was estimated by SDS. N. megalops was the only species in which female and male specimens were sexually active in both seasons sampled (Table 2); the other species were active only during spring. In autumn, only males of $T$. raschii and $M$. norvegica were mature, whereas all individuals of $T$. inermis were immature and/or sexually regressed (i.e. $20 \%$ of all $T$. inermis specimens were defined as neuter; Table 2). Sexual regression was also found in the $M$. norvegica specimens (e.g. autumn: 17\% neuters, spring: $7 \%$ neuters; Table 2 ).

\section{Metabolic rates}

Despite the seasonal differences found in biometric and individual life parameter investigations, respiration rates were the same in both seasons for all species sampled (see Table 1 for sampling details). Accordingly, for species comparisons, respiration rates were pooled for each experimental temperature (Fig. 2).

In $M$. norvegica and $N$. megalops, the increase in experimental temperature resulted in a significant (exponential) increase in oxygen consumption over the whole temperature range $\left(0\right.$ to $16^{\circ} \mathrm{C}_{i} M$. norvegica: $\mathrm{p}<0.0001, F_{8,71}=16.3 ; N$. megalops: $\mathrm{p}<$ $0.0001, F_{2,7}=56.6$; Fig. 2). Compared to the $4^{\circ} \mathrm{C}$ control temperature, the increase was first significant at $12^{\circ} \mathrm{C}$ (Fig. 2; Table S1 in the Supplement at www.intres.com/articles/suppl/m535p089_supp.pdf). Calculated $Q_{10}$ values ranged from 1.5 to 2.4 in $M$. norvegica and from 1.6 to 2.0 in N. megalops (Table 3). A literature comparison of respiration-temperature curves of $M$. norvegica from different climatic zones is given in Fig. 3. It shows that the respiration rates of the specimens sampled in our study most closely resembled those of specimens sampled in the Clyde Sea. Nevertheless, the effect of temperature on respiration rates showed the same pattern in all climatic zones (Fig. 3).

In contrast to $M$. norvegica and $N$. megalops, the species-specific respiratory performance during temperature increase in the 2 Thysanoessa species could be divided into 2 phases (Figs. 2 \& S1). As with $M$. norvegica and $N$. megalops, respiration rates increased exponentially in the first temperature increment $\left(0\right.$ to $\left.12^{\circ} \mathrm{C}\right)$. Compared to the $4^{\circ} \mathrm{C}$ control temperature, the increase was significant from $8^{\circ} \mathrm{C}$ in T. inermis and from $10^{\circ} \mathrm{C}$ for T. raschii (Fig. 2, Table S1). In the first phase, $Q_{10}$ values ranged from 1.8 to 3.3 in T. inermis and from 2.3 to 3.9 in T. raschii 

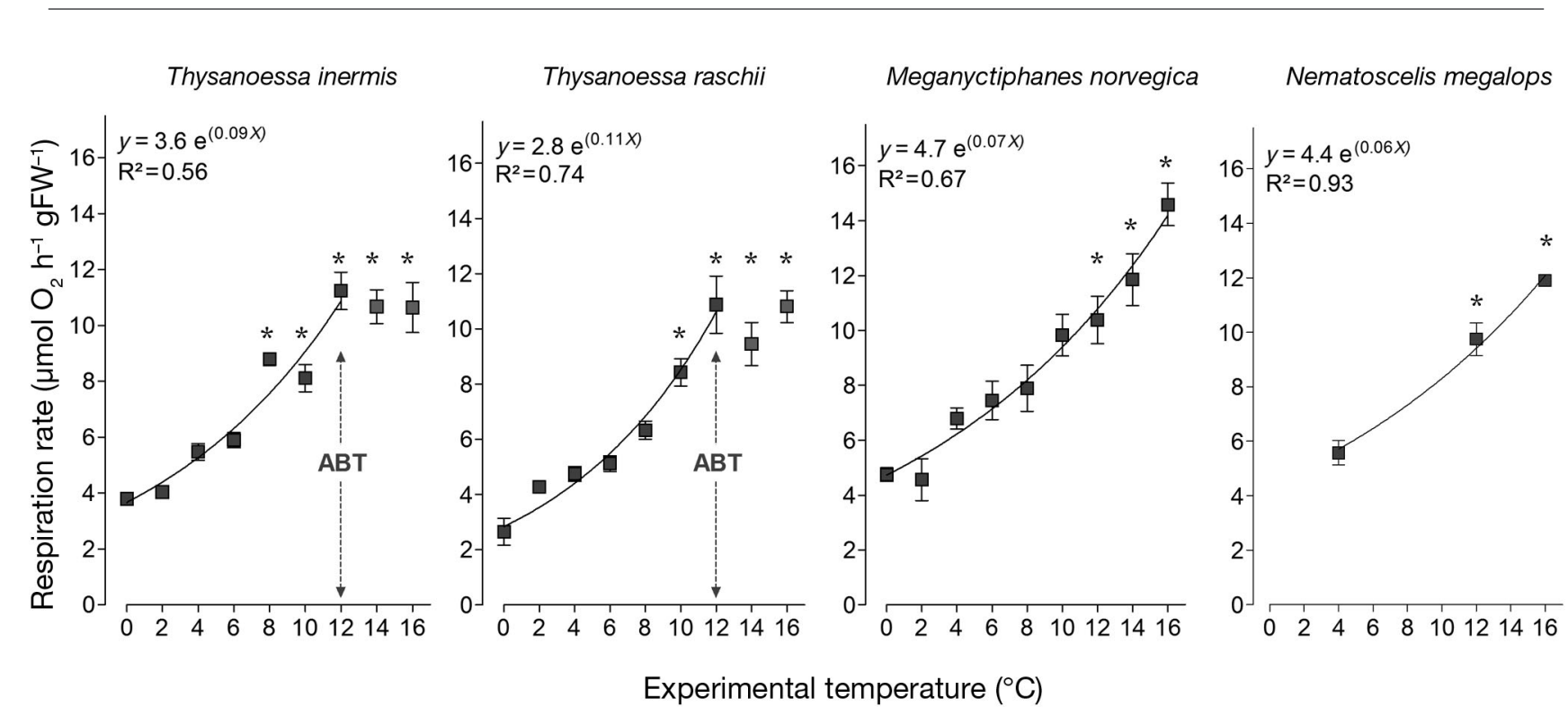

Experimental temperature $\left({ }^{\circ} \mathrm{C}\right)$

Fig. 2. Mean $( \pm \mathrm{SE})$ respiration rates of adult Thysanoessa inermis ( $\mathrm{n}=20$ to 35), T. raschii ( $\mathrm{n}=5$ to 9), Meganyctiphanes norvegica ( $\mathrm{n}=5$ to 19$)$ and Nematoscelis megalops $(\mathrm{n}=3$ to 4$)$ in relation to experimental temperature. ABT $=$ Arrhenius breakpoint temperature; ${ }^{*}$ significant difference from $4{ }^{\circ} \mathrm{C}$ control temperature $(\mathrm{p}<0.05 ; 1$-way ANOVA with post hoc Dunnett's test)

(Table 3). However, at experimental temperatures beyond $12^{\circ} \mathrm{C}$, mean oxygen consumption remained stable, fluctuating around $\sim 11 \mu \mathrm{mol} \mathrm{O}_{2} \mathrm{~h}^{-1} \mathrm{~g} \mathrm{FW}^{-1}$. Concomitantly, Arrhenius plots showed a sharp change in the slope of linear regression indicating the respiratory ABT (Figs. $2 \&$ S1), which was defined at $12^{\circ} \mathrm{C}$ in both species. $Q_{10}$ values in the second phase were 1.0 for $T$. inermis and 0.9 for $T$. raschii (Table 3).

In all species, $\mathrm{NH}_{4}-\mathrm{N}$ excretion rates were positively related to ambient temperature (Fig. 4). Seasonal differences were only found in the rates of $M$. norvegica (t-test at $8^{\circ} \mathrm{C}, \mathrm{p}<0.05, \mathrm{df}=6$; at $16^{\circ} \mathrm{C}, \mathrm{p}<$ $0.05, \mathrm{df}=7$ ). Here, mean excretion during spring was up to 3.5 times higher compared to the rates of specimens sampled during autumn (at 8 and $16^{\circ} \mathrm{C}_{i}$ Fig. 4 \& Table S1). In the other 3 species, mean excretion rates ranged from 0.3 to $1.8 \mu \mathrm{mol} \mathrm{NH}_{4}-\mathrm{N} \mathrm{h}^{-1} \mathrm{~g} \mathrm{FW}^{-1}$

Table 3. $Q_{10}$ values of the mean respiration rates from adult Thysanoessa inermis ( $\mathrm{n}=20$ to 35$), T$. raschii $(\mathrm{n}=5$ to 9$)$, Meganyctiphanes norvegica ( $\mathrm{n}=5$ to 19 ) and Nematoscelis megalops ( $\mathrm{n}=3$ to 4$) ; \mathrm{n}=$ number of individuals used in the temperature experiments

\begin{tabular}{|lccccc|}
\hline & \multicolumn{5}{c|}{ Temperature range $\left({ }^{\circ} \mathrm{C}\right)$} \\
& $0-4$ & $4-8$ & $4-12$ & $8-12$ & $12-16$ \\
\hline T. inermis & 2.5 & 3.3 & 2.5 & 1.8 & 0.9 \\
T. raschii & 2.8 & 2.3 & 3.0 & 3.9 & 1.0 \\
M. norvegica & 2.4 & 1.5 & 1.7 & 2.0 & 2.3 \\
N. megalops & - & - & 2.0 & - & 1.6 \\
\hline
\end{tabular}

in $T$. inermis ( 0 to $16^{\circ} \mathrm{C}$ ), from 0.8 to $2.3 \mu \mathrm{mol} \mathrm{NH}_{4}-\mathrm{N}$ $\mathrm{h}^{-1} \mathrm{~g} \mathrm{FW}^{-1}$ in $T$. raschii $\left(0\right.$ to $\left.16^{\circ} \mathrm{C}\right)$ and from 0.6 to $2.4 \mu \mathrm{mol} \mathrm{NH} \mathrm{NH}_{4}-\mathrm{N} \mathrm{h}^{-1} \mathrm{~g} \mathrm{FW}^{-1}$ in $\mathrm{N}$. megalops $\left(4\right.$ to $16^{\circ} \mathrm{C}_{\text {; }}$ Fig. 4 \& Table S1).

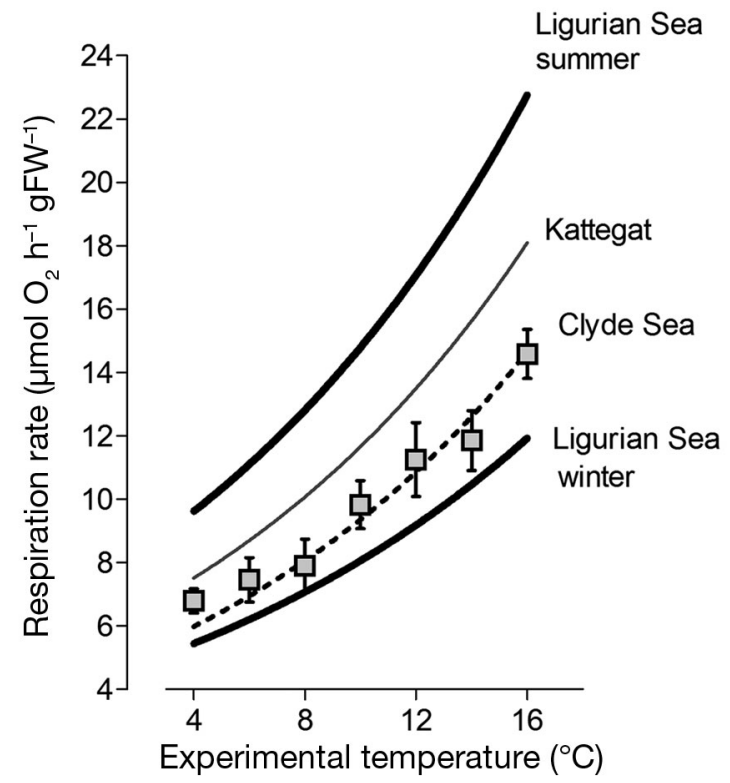

Fig. 3. Comparison to literature. Temperature curve of mean $( \pm \mathrm{SE})$ respiration rates of adult Meganyctiphanes norvegica (squares; $\mathrm{n}=5$ to 19 ) in comparison to rates of $M$. norvegica from different climatic zones: Ligurian Sea summer, Kattegat (summer and winter), Clyde Sea (summer and winter) and Ligurian Sea winter (connecting lines; values converted from Saborowski et al. 2002 applying a dry to fresh weight conversion factor of $25 \%$ ) 

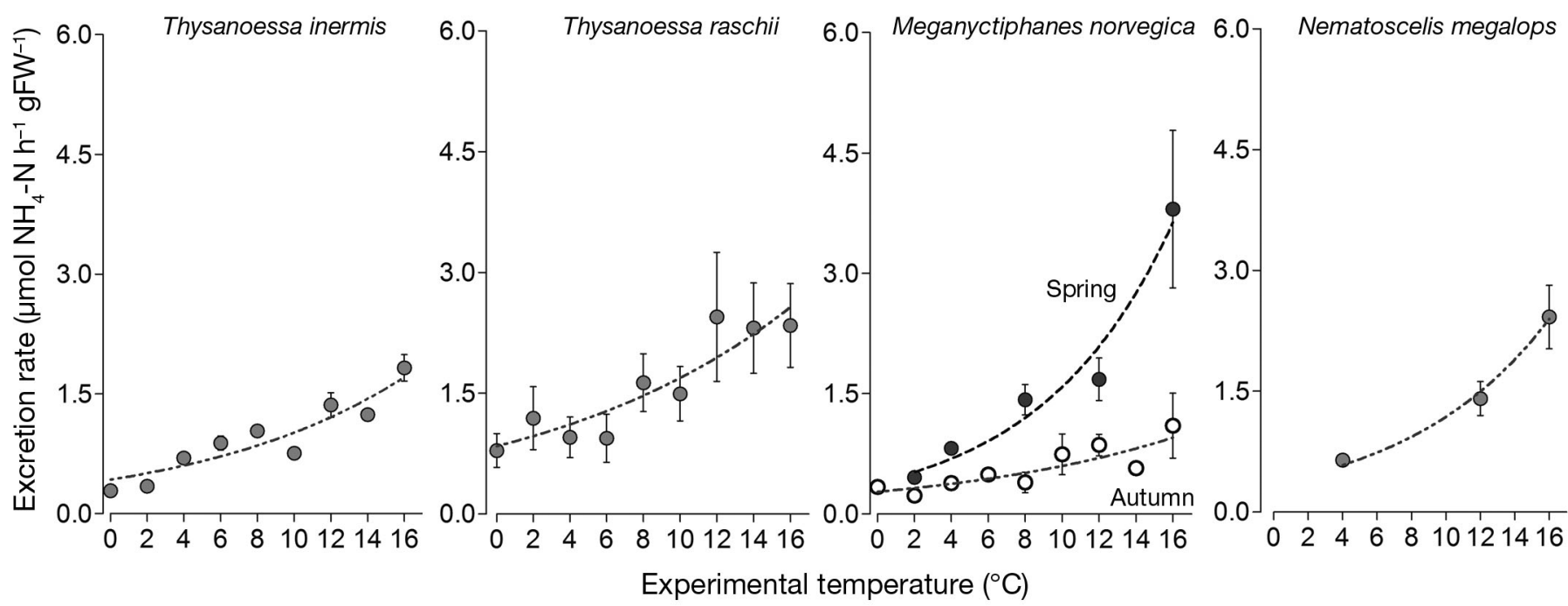

Fig. 4. Mean $( \pm \mathrm{SE})$ excretion rates of adult Thysanoessa inermis ( $\mathrm{n}=20$ to 35), T. raschii ( $\mathrm{n}=5$ to 9), Meganyctiphanes norvegica ( $\mathrm{n}=5$ to 19$)$ and Nematoscelis megalops $(\mathrm{n}=3$ to 4$)$ in relation to experimental temperature. For $M$. norvegica, rates are shown for spring and autumn

Thysanoessa inermis

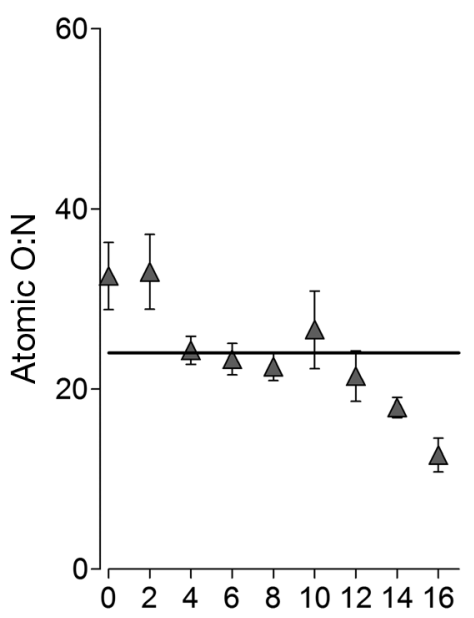

Thysanoessa raschii

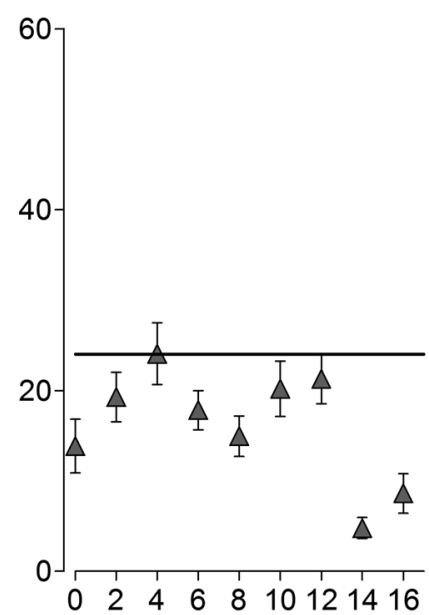

Meganyctiphanes norvegica

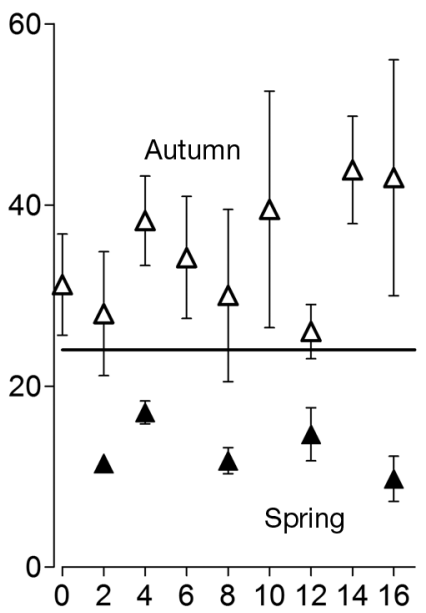

Nematoscelis megalops

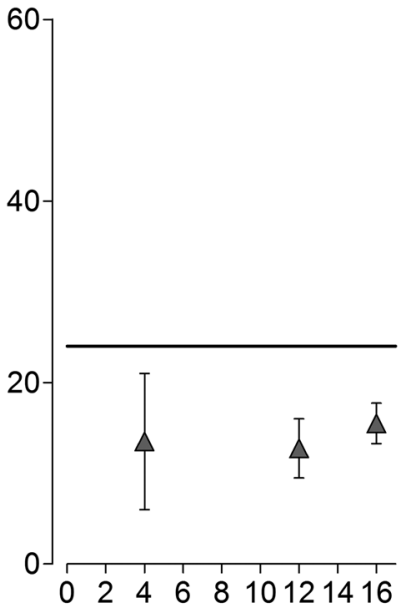

\section{Experimental temperature $\left({ }^{\circ} \mathrm{C}\right)$}

Fig. 5. Mean $( \pm \mathrm{SE})$ oxygen to nitrogen $(\mathrm{O}: \mathrm{N})$ ratios for adult Thysanoessa inermis ( $\mathrm{n}=20$ to 35), T. raschii $(\mathrm{n}=5$ to 9), Meganyctiphanes norvegica ( $\mathrm{n}=5$ to 19 ) and Nematoscelis megalops ( $\mathrm{n}=3$ to 4 ) in relation to experimental temperature. For $M$. norvegica, rates are shown for spring and autumn. Solid line at O:N $=24$ indicates equal use of proteins and lipids

(Mayzaud \& Conover 1988)

The atomic O:N ratio was derived from the measurements of respiration and excretion. In both Thysanoessa species, this ratio was negatively related to increasing temperatures. For $T$. inermis, the highest values were $>30$ at 0 and $2{ }^{\circ} \mathrm{C}$, respectively (Fig. 5, Table $\mathrm{S} 1$ ). The maximum O:N ratio of $T$. raschii was $\sim 24$ at $4{ }^{\circ} \mathrm{C}$. Lowest values were calculated at temperatures above the ABT (O:N ratio $<18$ in $T$. inermis and $<9$ in $T$. raschii). In contrast, the O:N ratios of $M$. norvegica and $N$. megalops were not influenced by experimental temperature. In $N$. megalops the ratio was <24. In $M$. norvegica, mean O:N ratios differed between sampling seasons. In autumn, mean O:N ratios were $>24$, with a minimum of 26.0 at $12^{\circ} \mathrm{C}$ and a maximum of 43.8 at $14^{\circ} \mathrm{C}$, respectively (Fig. 5, Table S1). In comparison, spring ratios were $<24$ and ranged from a maximum of $17.1\left(4^{\circ} \mathrm{C}\right)$ to a minimum of $9.7\left(16^{\circ} \mathrm{C}\right)$. 


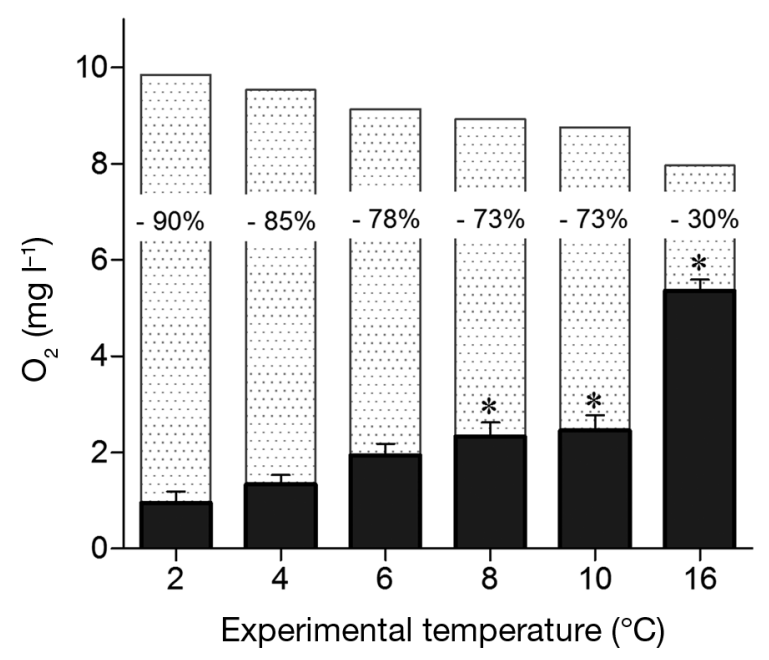

Fig. 6. Minimum tolerable ambient oxygen concentration (dark bars $=$ beginning of immobilization) of adult Thysanoessa inermis ( $\mathrm{n}=8$ for each) in relation to experimental temperature. Percentages give the difference from the initial concentrations (dotted bars $=100 \% \mathrm{O}_{2}$ saturation at respective experimental temperature). Values are given as means $\pm \mathrm{SE}^{*}{ }^{*}$ significant difference from $4^{\circ} \mathrm{C}(\mathrm{p}<0.05$; 1-way ANOVA with post hoc Dunnett's test)

\section{Minimum tolerable ambient oxygen concentration in $T$. inermis}

The MTO concentration for T. inermis was positively related to ambient experimental temperatures (Fig. 6). In comparison to the $4^{\circ} \mathrm{C}$ control group (MTO $=1.3 \pm$ $0.2 \mathrm{mg} \mathrm{l}^{-1}$ ), these values were significantly higher at temperatures $>8^{\circ} \mathrm{C}(\mathrm{p}<0.0001, F=38.1)$. At $8^{\circ} \mathrm{C}$, the average specimen did not endure (i.e. became physically immobile) ambient oxygen concentrations below $2.3 \pm 0.2 \mathrm{mg} \mathrm{l}^{-1}$ (Fig. 6). The same was found for specimens incubated at $10^{\circ} \mathrm{C}\left(\mathrm{MTO}=2.4 \pm 0.3 \mathrm{mg} \mathrm{l}^{-1}\right)$. At $16^{\circ} \mathrm{C}, T$. inermis became physically immobile at a mean ambient oxygen concentration of $5.3 \pm 0.2 \mathrm{mg}$ $1^{-1}(=70 \%$ of initial concentration; Fig. 6$)$, which is only about one-fourth the resistance compared to the control group $\left(4^{\circ} \mathrm{C}\right)$ and/or one-sixth compared to those incubated at $2^{\circ} \mathrm{C}\left(\mathrm{MTO}=0.9 \pm 0.2 \mathrm{mg} \mathrm{l}^{-1}\right)$.

\section{DISCUSSION}

\section{Health of the krill species}

Our study showed that all specimens sampled (arcto-boreal Thysanoessa inermis, arcto-boreal $T$. raschii, temperate-boreal Meganyctiphanes norvegica and subtropical-temperate Nematoscelis megalops) were healthy. None of the individuals had empty stomachs, which indicated active feeding for all spe- cies in both seasons sampled. However, the colour of the hepatopancreas provided more detailed information on the species' nutritional condition. HPP colour is an indicator of the individual's long-term feeding activity (i.e. the specific source of nutrition), and can vary between colourless (indicating no feeding), green (phytoplanktonic diet) and white, yellow, orange and red (zooplanktonic diet; e.g. Morris et al. 1983, Buchholz 1989, Meyer et al. 2010). Accordingly, despite stomach fullness, the colourless HPP in the Thysanoessa species and $N$. megalops suggested only occasional feeding. In contrast, the coloured HPP of $N$. megalops during autumn and $M$. norvegica during both seasons indicated a considerable fraction of zooplankton in these species' diet, and highlights their carnivorous tendency (e.g. feeding on lipid-rich calanoid copepods; Falk-Petersen et al. 2009, Huenerlage et al. 2014). The assumption of carnivory in $M$. norvegica was further supported by oil droplets present in some of the stomachs of those specimens sampled during autumn, which most likely originated from copepod ingestion.

$M$. norvegica was the only species that showed seasonal differences in excretion rates, with the highest rates occurring in the early spring samples. Excretion closely relates to the type of food ingested, i.e. high phytoplankton concentrations correspond to high ammonium excretion rates (Saborowski et al. 2002). Therefore, we suggest that $M$. norvegica shows more intensive feeding compared to the Thysanoessa species and N. megalops, and thus it is most likely the first krill species to utilize the phytoplankton bloom at the beginning of spring.

Sexual maturity was monitored as a first indicator of each species' reproductive potential. Our investigations showed that all sampled individuals were sexually active during spring 2013. Due to time limitations, it was not possible to follow the onset and duration of mating or spawning periods. However, other recent studies (e.g. Niehoff et al. 2013, Buchholz at al. 2010, authors' unpubl. data) have detected juvenile Thysanoessa spp. and $M$. norvegica from sediment traps and net catches during the spring in the wider Kongsfjord area, indicating successful spawning. Juvenile stages of $N$. megalops have not been detected in this region, even though this species is sexually active at the end of the summer. The other 3 species exhibited sexual regression, which is a typical functional adaptation to reduce metabolic costs when individuals are unable to sufficiently cover reproductive needs, for example during overwintering (e.g. Dalpadado \& Ikeda 1989, CuzinRoudy \& Buchholz 1999, Huenerlage et al. 2015). 


\section{Temperature effects on respiration rates}

Our experiments revealed that both the temperateboreal $M$. norvegica and the subtropical-temperate $N$. megalops were respiratorily able to compensate for experimental changes in ambient water temperatures and associated changes in energy (oxygen) demands. Respiration rates were positively correlated to temperature and showed a characteristic $Q_{10}$ relationship over the whole temperature range investigated (e.g. $Q_{10} 1.6$ to 2.7 computed for marine zooplankton including krill; Ivleva 1980, Ikeda 1985). Remarkably, the metabolic reactions to temperature were the same compared to previous investigations performed at lower latitudes. In $M$. norvegica, our Kongsfjord data $\left(79^{\circ} \mathrm{N}\right)$ were comparable to populations sampled in the Kattegat $\left(57^{\circ} \mathrm{N}\right.$, summer and winter) and the Ligurian Sea $\left(43^{\circ} \mathrm{N}\right.$, summer), and correlated best to specimens sampled from the Clyde Sea $\left(56^{\circ} \mathrm{N}\right.$, summer and winter; Saborowski et al. 2002). In N. megalops, temperature-dependent respiration rates were similar over the entire temperature range $\left(4\right.$ to $20^{\circ} \mathrm{C}$ ) compared to specimens sampled from the subtropical-tropical Northern Benguela Current located in the southeastern Atlantic at $\sim 23^{\circ} \mathrm{S}$ (Werner et al. 2012). This comparison among climatic zones indicates that temperature acclimatization (see Clarke 1991 for definition) does not seem to play a significant role in either krill species. Furthermore, at least between 0 and $16^{\circ} \mathrm{C}$ ( $M$. norvegica) and 4 and $20^{\circ} \mathrm{C}$ (N. megalops), the specimens have not yet reached their thermal limits in all regions sampled, and experimentally were not yet exposed to their specific upper or lower respiratory pejus temperatures (see below). These findings highlight the considerable metabolic plasticity of these species, and support observations of their increased abundance at higher latitudes (e.g. Zhukova et al. 2009). However, it remains unclear whether the subtropical-temperate species is adapted to temperatures $<4^{\circ} \mathrm{C}$. In comparison to the temperate-boreal $M$. norvegica, a low pejus temperature between 0 and $4^{\circ} \mathrm{C}$ in $N$. megalops may affect its survival, which may suggest population failure during transport northward.

In comparison to $M$. norvegica and $N$. megalops, the metabolic response to increasing temperatures in the 2 Thysanoessa species was remarkably different, especially at the upper temperature ranges. In both T. inermis and T. raschii, an acute increase of experimental temperatures resulted in considerable respiratory disturbance. The ABT was defined at $\sim 12^{\circ} \mathrm{C}$, after which respiration rates levelled out and became independent of further temperature increase, accom- panied by higher sensitivity to decreasing oxygen concentrations inside the respiration chambers (this study) and increased mortality during acclimation (K. Huenerlage et al. unpubl. data). According to Frederich \& Pörtner (2000), this turning point most likely indicates the beginning of pejus hemolymph oxygenation, and can therefore be equated to these species' upper pejus temperature limit (TpII). The effect of pejus temperature was further observed by a decrease of the $Q_{10}$ values calculated at temperatures $>12^{\circ} \mathrm{C}$ (Pörtner \& Knust 2007). Consequently, the ABT characterized the upper limit of temperatureinduced oxygen demand in both Thysanoessa species, and accordingly their limit of metabolic (cardiovascular) capacity, likely followed by the onset of anaerobic metabolism (sensu Sokolova \& Pörtner 2003).

However, metabolic response to short-term induced temperature changes may only reflect an individual's passive survival strategy, and hence, timelimited tolerance. The specific thermal tolerance of an organism results from the complex interaction of small-scale constituents (e.g. molecules, organelles, cells and tissues) that determine the mechanisms responsible for long-term survival-including the success of individual growth and reproduction, and thus, overall population performance and persistence (Pörtner 2002, Somero 2010). It is therefore interesting that after longer exposure to only $10^{\circ} \mathrm{C}, \mathrm{T}$. inermis specimens did not reduce their metabolic rates (due to possible further acclimation effects; K. Huenerlage et al. unpubl. data) and morphologically exhibited a red colouring of the exoskeleton, known as an indication of physiological stress (Buchholz 2003, Auerswald et al. 2008). Furthermore, investigations on the molecular repair mechanisms of $T$. inermis (the heatinduced gene expression of the molecular chaperone 'heat shock protein 70' [Hsp70]), already resulted in significant expression at the $10^{\circ} \mathrm{C}$ experimental temperature (K. Cascella pers. comm., K. Huenerlage et al. unpubl. data). Consequently, especially by considering long-term changes in temperature, the thermal limit for Thysanoessa species may even be below $12^{\circ} \mathrm{C}$.

As a result, reports on these species' decreasing abundances at lower latitudes (e.g. in the Behring Sea and the Newfoundland and Labrador shelf ecosystem; Coyle et al. 2008, 2011, Hunt et al. 2011, Colbourne et al. 2013) may be related to their metabolic thermal limit. In the Newfoundland and Labrador shelf ecosystem, for instance, persistent warming anomalies occasionally exceed the upper metabolic pejus temperatures suggested for the Thysanoessa 
species (summer surface temperatures up to $15^{\circ} \mathrm{C}$; see Colbourne et al. 2013). Consistent warming may have led to a loss of metabolic performance in both species, and thus may have altered the long-term population persistence of $T$. inermis and $T$. raschii within this region or at lower latitudes, respectively. Alternatively, our findings may highlight these species' strict arcto-boreal biogeographic distribution associated with colder water temperatures.

To our knowledge, respiratory upper thermal limits have not yet been detected in any other euphausiid species. At lower temperature ranges, respiration curves of both $T$. inermis and $T$. raschii are available in the literature (Sameoto 1976, Ikeda \& Skjoldal 1989, Agersted et al. 2011) and are consistent with the species-specific respiration rates measured in this study. However, none of these investigations were conducted at temperatures at which the specimens may have exceeded their thermal respiratory capacity. This type of experiment is needed (especially with regard to species-specific thermal limits) in order to predict the persistence and possible establishment of populations in a given environment (Pörtner \& Farrell 2008).

\section{CONCLUSIONS}

Our study on the upper thermal tolerances of krill from the Arctic offers an explanation for why both arcto-boreal Thysanoessa inermis and T. raschii were less numerous during warm periods at lower latitudes (e.g. Coyle et al. 2008, Hunt et al. 2011). Furthermore, this study highlights the metabolic plasticity of the temperate-boreal Meganyctiphanes norvegica and subtropical-temperate Nematoscelis megalops, which supports the presence of higher stocks at lower latitudes as well as in a high-Arctic fjord. The temperature-induced respiration curves indicate that both species are adapted to a wide range of temperature fluctuations. However, low pejus temperatures may occur in $N$. megalops, which may constrain its persistence at high latitudes. In conclusion, the metabolic plasticity of $M$. norvegica may allow recruitment in the 'Atlantification' of the high-Arctic Kongsfjord ecosystem, whereas Thysanoessa species are unlikely to acclimate when water temperatures increase.

Acknowledgements. We thank the captains of the Kings Bay AS workboat MS 'Teisten'. We are grateful for the professional support by the lab leaders of the Kings Bay Marine Lab, the AWIPEV station leaders and (logistic) engineers at Ny-Ålesund, Spitsbergen. The data from the COSYNA data web portal were originally provided by Prof. Dr. Philipp Fischer (AWI), Dr. Gisbert Breitbach (HZG), Prof. Dr. Burkard Baschek (HZG) and Dr. Friedhelm Schroeder (HZG). We are grateful to James A. Bradley (University of Bristol, UK) for the final language edit. This work was supported by the French-German AWIPEV project KOP 124, RIS ID 3451.

\section{LITERATURE CITED}

Agersted MD, Nielsen TG, Munk P, Vismann B, Arendt KE (2011) The functional biology and trophic role of krill (Thysanoessa raschii) in a Greenlandic fjord. Mar Biol 158:1387-1402

Auerswald L, Freier U, Lopata A, Meyer B (2008) Physiological and morphological colour change in Antarctic krill, Euphausia superba: a field study in the Lazarev Sea. J Exp Biol 211:3850-3858

Buchholz F (1989) Moult cycle and seasonal activities of chitinolytic enzymes in the integument and digestive tract of the Antarctic krill, Euphausia superba. Polar Biol 9:311-317

Buchholz F (2003) Experiments on the physiology of southern and northern krill, Euphausia superba and Meganyctiphanes norvegica, with emphasis on moult and growtha review. Mar Freshwat Behav Physiol 36:229-247

> Buchholz F, Buchholz C, Weslawski JM (2010) Ten years after: krill as indicator of changes in the macro-zooplankton communities of two Arctic fjords. Polar Biol 33:101-113

> Buchholz F, Werner T, Buchholz C (2012) First observation of krill spawning in the high Arctic Kongsfjorden, west Spitsbergen. Polar Biol 35:1273-1279

Clarke A (1991) What is cold adaptation and how should we measure it? Am Zool 31:81-92

Colbourne EB, Craig J, Fitzpatrick C, Senciall D, Stead P, Bailey W (2013) An assessment of the physical oceanographic environment on the Newfoundland and Labrador Shelf in NAFO Subareas 2 and 3 during 2012. NAFO SCR Doc 13/018:1-28

> Coyle KO, Pinchuk AI, Eisner LB, Napp JM (2008) Zooplankton species composition, abundance and biomass on the eastern Bering Sea shelf during summer: the potential role of water-column stability and nutrients in structuring the zooplankton community. Deep-Sea Res II 55:1775-1791

Coyle KO, Eisner LB, Mueter FJ, Pinchuk AI and others (2011) Climate change in the southeastern Bering Sea: impacts on pollock stocks and implications for the oscillating control hypothesis. Fish Oceanogr 20:139-156

> Cuzin-Roudy J (1993) Reproductive strategies of the Mediterranean krill, Meganyctiphanes norvegica and the Antarctic krill, Euphausia superba (Crustacea: Euphausiacea). Invertebr Reprod Dev 23:105-114

Cuzin-Roudy J, Buchholz F (1999) Ovarian development and spawning in relation to the moult cycle in northern krill, Meganyctiphanes norvegica (Crustacea: Euphausiacea), along a climatic gradient. Mar Biol 133:267-281

Dahlhoff E, O'Brien J, Somero GN, Vetter RD (1991) Temperature effects on mitochondria from hydrothermal vent invertebrates: evidence for adaptation to elevated and variable habitat temperatures. Physiol Zool 64:1490-1508

> Dalpadado P, Ikeda T (1989) Some observations on moulting, growth and maturation of krill (Thysanoessa inermis) from the Barents Sea. J Plankton Res 11:133-139

Einarsson H (1945) Euphausiacea. I. Northern Atlantic species. Bianco Luno, Copenhagen

Falk-Petersen S, Mayzaud P, Kattner G, Sargent JR (2009) 
Lipids and life strategy of Arctic Calanus. Mar Biol Res 5: 18-39

Frederich M, Pörtner HO (2000) Oxygen limitation of thermal tolerance defined by cardiac and ventilatory performance in spider crab, Maja squinado. Am J Physiol Regul Integr Comp Physiol 279:R1531-R1538

> Hop H, Pearson T, Hegseth EN, Kovacs KM and others (2002) The marine ecosystem of Kongsfjorden, Svalbard. Polar Res 21:167-208

Hop H, Falk-Petersen S, Svendsen H, Kwasniewski S and others (2006) Physical and biological characteristics of the pelagic system across Fram Strait to Kongsfjorden. Prog Oceanogr 71:182-231

Huenerlage K, Graeve M, Buchholz F (2014) Lipid composition and trophic relationships of krill species in a high Arctic fjord. Polar Biol, doi:10.1007/s00300-014-1607-6

Huenerlage K, Graeve M, Buchholz C, Buchholz F (2015) The other krill: overwintering physiology of adult Thysanoessa inermis (Euphausiacea) from the high-Arctic Kongsfjord. Aquat Biol 23:225-235

Hunt GL, Coyle KO, Eisner LB, Farley EV and others (2011) Climate impacts on eastern Bering Sea foodwebs: a synthesis of new data and an assessment of the oscillating control hypothesis. ICES J Mar Sci 68:1230-1243

- Ikeda T (1985) Metabolic rates of epipelagic marine zooplankton as a function of body mass and temperature. Mar Biol 85:1-11

Ikeda T, Skjoldal HR (1989) Metabolism and elemental composition of zooplankton from the Barents Sea during early Arctic summer. Mar Biol 100:173-183

Ivleva IV (1980) The dependence of crustacean respiration rate on body mass and habitat temperature. Int Rev Gesamten Hydrobiol Hydrograph 65:1-47

Kwasniewski S, Gluchowska M, Walkusz W, Karnovsky NJ and others (2012) Interannual changes in zooplankton on the West Spitsbergen Shelf in relation to hydrography and their consequences for the diet of planktivorous seabirds. ICES J Mar Sci 69:890-901

Mauchline J, Fisher LR (1969) The biology of euphausiids. Advances in Marine Biology 7: Elsevier Science \& Technology, Amsterdam

Mayzaud P, Conover RJ (1988) O:N atomic ratio as a tool to describe zooplankton metabolism. Mar Ecol Prog Ser 45: 289-302

Meyer B, Auerswald L, Siegel V, Spahić S and others (2010) Seasonal variation in body composition, metabolic activity, feeding, and growth of adult krill Euphausia superba in the Lazarev Sea. Mar Ecol Prog Ser 398:1-18

Morris DJ, Ward P, Clarke A (1983) Some aspects of feeding in the Antarctic krill, Euphausia superba. Polar Biol 2: 21-26

> Niehoff B, Schmithüsen T, Knüppel N, Daase M, Czerny J, Boxhammer T (2013) Mesozooplankton community development at elevated $\mathrm{CO}_{2}$ concentrations: results from a mesocosm experiment in an Arctic fjord. Biogeosciences 10:1391-1406

Polyakov I, Timokhov L, Dmitrenko I, Ivanov V and others (2007) Observational program tracks Arctic Ocean transition to a warmer state. Eos Trans AGU 88:398-399, doi: 10.1029/2007EO400002

Editorial responsibility: Marsh Youngbluth, Fort Pierce, Florida, USA
Pörtner HO (2001) Climate change and temperaturedependent biogeography: oxygen limitation of thermal tolerance in animals. Naturwissenschaften 88:137-146

$>$ Pörtner HO (2002) Climate variations and the physiological basis of temperature dependent biogeography: systemic to molecular hierarchy of thermal tolerance in animals. Comp Biochem Physiol A Mol Integr Physiol 132:739-761

Pörtner HO, Knust R (2007) Climate change affects marine fishes through the oxygen limitation of thermal tolerance. Science 315:95-97

Pörtner HO, Farrell AP (2008) Physiology and climate change. Science 322:690-692

> Saborowski R, Bröhl S, Tarling G, Buchholz F (2002) Metabolic properties of northern krill, Meganyctiphanes norvegica, from different climatic zones. I. Respiration and excretion. Mar Biol 140:547-556

Sameoto DD (1976) Respiration rates, energy budgets, and molting frequencies of three species of euphausiids found in the Gulf of St. Lawrence. J Fish Res Board Can 33:2568-2576

Sokolova IM, Pörtner HO (2003) Metabolic plasticity and critical temperatures for aerobic scope in a eurythermal marine invertebrate (Littorina saxatilis, Gastropoda: Littorinidae) from different latitudes. J Exp Biol 206:195-207

Solorzano L (1969) Determination of ammonia in natural waters by the phenolhypochlorite method. Limnol Oceanogr 14:799-801

Somero GN (2005) Linking biogeography to physiology: evolutionary and acclimatory adjustments of thermal limits. Front Zool 2:1-9

Somero GN (2010) The physiology of climate change: how potentials for acclimatization and genetic adaptation will determine 'winners' and 'losers'. J Exp Biol 213:912-920

Spielhagen RF, Werner K, Sørensen SA, Zamelczyk K and others (2011) Enhanced modern heat transfer to the Arctic by warm Atlantic water. Science 331:450-453

Svendsen H, Beszczynska-Møller A, Hagen JO, Lefauconnier B and others (2002) The physical environment of Kongsfjorden-Krossfjorden, an Arctic fjord system in Svalbard. Polar Res 21:133-166

Timofeyev SF (1993) Distribution and age composition of euphausiids in waters around the Spitsbergen Archipelago. Oceanology 33:89-92

van't Hoff MJH (1884) Etudes de dynamique chimique. Recl Trav Chim Pays Bas 3:333-336

Werner T, Hünerlage K, Verheye H, Buchholz F (2012) Thermal constraints on the respiration and excretion rates of krill, Euphausia hanseni and Nematoscelis megalops, in the northern Benguela upwelling system off Namibia. Afr J Mar Sci 34:391-399

Weslawski JM, Pedersen G, Petersen SF, Porazinski K (2000) Entrapment of macroplankton in an Arctic fjord basin, Kongsfjorden, Svalbard. Oceanologia 42:57-69

Williams PJLB, del Giorgio PA (2005) Respiration in aquatic ecosystems: history and background. In: del Giorgio PA, Williams PJLB (eds) Respiration in aquatic ecosystems. Oxford University Press, Oxford, p 1-17

Zhukova NG, Nesterova VN, Prokopchuk IP, Rudneva GB (2009) Winter distribution of euphausiids (Euphausiacea) in the Barents Sea (2000-2005). Deep-Sea Res II 56:1959-1967

Submitted: October 30, 2014; Accepted: June 24, 2015

Proofs received from author(s): August 26, 2015 